\title{
Diet of larval Ambystoma rivulare (Caudata: Ambystomatidae), a threatened salamander from the Volcán Nevado de Toluca, Mexico
}

\author{
Julio A. Lemos-Espinal ${ }^{1}$, Geoffrey R. Smith ${ }^{2}$, Guillermo A. Woolrich-Piña ${ }^{3}$, and Raymundo \\ Montoya-Ayala ${ }^{4}$ \\ ${ }^{1}$ Laboratorio de Ecología - UBIPRO, Facultad de Estudios Superiores Iztacala, Av. Los Barrios 1, Los Reyes Iztacala, \\ Tlalnepantla, Estado de México, 54090, Mexico. E-mail: lemos@unam.mx. \\ ${ }^{2}$ Department of Biology, Denison University, Granville, Ohio 43023, USA. E-mail: smithg@ denison.edu. \\ ${ }^{3}$ Laboratorio de Paleontología y Geobiología, ESIA Ticomán - IPN, Av. Ticomán 600, Col. Ticomán, D.F. 07340, Mexico. \\ E-mail: gwoolrich@ipn.mx. \\ ${ }^{4}$ Laboratorio de Cómputo - UBIPRO, Facultad de Estudios Superiores Iztacala, Av. Los Barrios 1, Los Reyes Iztacala, \\ Tlalnepantla, Estado de México, 54090, Mexico. E-mail: rmontoya@campus.iztacala.unam.mx.
}

\begin{abstract}
Diet of larval Ambystoma rivulare (Caudata: Ambystomatidae), a threatened salamander from the Volcán Nevado de Toluca, Mexico. Several species of salamander in the genus Ambystoma occur in the mountains surrounding Mexico City and are considered at risk of extinction. However, little is known about their ecology and natural history. The Toluca Stream Siredon (Ambystoma rivulare) is classified as "Data Deficient" by the IUCN, and considered "Threatened" under Mexican law. From October 2013 to September 2014, we examined the diet of larval A. rivulare from a stream on the Volcán Nevado de Toluca in Mexico to provide insight into the suitability of the habitat to support this population of salamanders. Ostracods accounted for approximately $90 \%$ of all prey items consumed by larval $A$. rivulare. The number of ostracods found in stomachs increased with individual body size, but the proportion of ostracods in stomachs did not vary with body size. Nematodes were observed in approximately one third of the stomachs we examined. The diversity of prey in the diet of A. rivulare in the stream we studied is low and dominated by a single prey taxon, ostracods. Our results suggest that if environmental conditions in the stream change such that ostracods are negatively affected then the longterm persistence of this population of $A$. rivulare might be in jeopardy.
\end{abstract}

Keywords: empty stomachs, nematodes, ostracods, stomach contents.

Received 19 September 2014.

Accepted 4 Junel 2015.

Distributed June 2015. 


\begin{abstract}
Resumen
Dieta de larvas de Ambystoma rivulare (Caudata: Ambystomatidae), una especie de salamandra amenazada del Volcán Nevado de Toluca, México. Varias especies de salamandras del género Ambystoma que habitan en las montañas que rodean a la Ciudad de México están consideradas en peligro de extinción. Sin embargo, se conoce poco sobre su ecología e historia natural. El Ajolote Arroyero de Toluca (Ambystoma rivulare) está clasificado como "Información Deficiente" por la UICN, y como "Amenazada" bajo la ley mexicana. De octubre 2013 a septiembre 2014, examinamos la dieta de larvas de A. rivulare que habitan en un arroyo del Volcán Nevado de Toluca en México. El estudio de la dieta de larvas de A. rivulare puede darnos el conocimiento necesario para saber cuáles son las características del hábitat que esta salamandra requiere para sobrevivir. Los ostrácodos representaron casi el $90 \%$ de las presas consumidas por larvas de A. rivulare. El número de ostrácodos encontrados en el estómago de un individuo incrementó con el tamaño corporal. Se observaron nematodos en tan sólo un poco más de un tercio de los estómagos examinados. En conclusión, la dieta de A. rivulare en el arroyo que estudiamos es poco diversa y está dominada por una sola presa, ostrácodos. Estos resultados sugieren que si las condiciones ambientales de este arroyo cambiarán tal que los ostrácodos se vieran afectados negativamente entonces la persistencia a largo plazo de esta población de A. rivulare podría estar en peligro.
\end{abstract}

Palabras clave: contenido estomacal, estómagos vacíos, nematodos, ostrácodos.

\begin{abstract}
Resumo
Dieta de larvas de Ambystoma rivulare (Caudata: Ambystomatidae), uma salamandra ameaçada de Volcán Nevado de Toluca, México. Várias espécies de salamandra do gênero Ambystoma ocorrem nas montanhas em torno da Cidade do México e são consideradas em risco de extinção. Contudo, pouco é conhecido sobre sua ecologia e história natural. Ambystoma rivulare é classificada como Deficiente em Dados pela IUCN e considerada Ameaçada pela lei mexicana. De outubro de 2013 a setembro de 2014 examinamos a dieta de larvas de A. rivulare de um riacho de Volcán Nevado de Toluca, México, para obter informações sobre a adequabilidade do habitat para sustentar essa população de salamandras. Ostrácodes responderam por cerca de $90 \%$ de todos os itens alimentares consumidos pelas larvas de A. rivulare. O número de ostrácodes encontrado nos estômagos aumentou com o tamanho corpóreo dos indivíduos, mas a proporção de ostrácodes não variou com o tamanho do corpo. Nemátodes foram observados em cerca de $1 / 3$ dos estômagos examinados. A diversidade de presas na dieta de A. rivulare no riacho estudado é baixa e dominada por um único táxon, ostrácodes. Nossos resultados sugerem que, se as condições ambientais do riacho mudarem de maneira que os ostrácodes sejam negativamente afetados, a persistência de longa duração dessa população poderá tornar-se ameaçada.
\end{abstract}

Palavras-chave: conteúdo estomacal, estômagos vazios, nemátodes, ostrácodes.

\section{Introduction}

The herpetofauna of Mexico is markedly unique, with high levels of diversity and endemicity (Flores-Villela 1993). Unfortunately, many of these endemics are under increasing threat from a variety of anthropogenic sources (Frías-Alvarez et al. 2010). Among the more threatened groups of amphibians and reptiles of
Mexico are the salamanders, and in particular, the Ambystomatids (Frías-Alvarez et al. 2010).

Several species of Ambystoma occur in the mountains surrounding Mexico City (LemosEspinal et al. 1999b). Many of these species and populations are considered at risk of extinction (see Frías-Alvarez et al. 2010 for review). Threats to these populations include habitat loss, introduced fish, pollution, and poaching (Lemos- 
Espinal et al. 1999b, Griffiths et al. 2004, Robles-Mendoza et al. 2009). In addition, several species of Ambystoma in Mexico have been found to be infected with the fungal pathogen Batrachochytrium dendrobatidis (FríasAlvarez et al. 2008). A number of recent studies have focused on the ecology and conservation of the Axolotl, Ambystoma mexicanum (e.g., Griffiths et al. 2004, Bride et al. 2008, Contreras et al. 2009, Chaparro-Herrera et al. 2013). Fewer studies have been carried out to understand the ecology and natural history of other endangered or threatened, endemic species of Ambystoma.

Ambystoma rivulare is classified as "Data Deficient" by the IUCN and considered "Threatened" under Mexican law (Frías-Alvarez et al. 2010). A survey from 1991-1996 in the Transvolcanic Belt found A. rivulare in only two localities, both of which were of highly disturbed streams (Lemos-Espinal et al. 1999b). The basic ecology and natural history of $A$. rivulare is poorly known, except for limited observations on its reproduction (Legorreta-Balbuena et al. 2014), eggs and larvae (Brandon and Altig 1973), cannibalism (Lemos-Espinal et al. 1999a), and habitat use (Bille 2009) (see also Huacuz Elias 2003).

We examined the diet of larval Ambystoma rivulare from a stream on the Volcán Nevado de Toluca in Mexico. Demographic modeling suggests that the egg and larval stages are particularly important for population growth and stability in some Mexican Ambystoma (Zambrano et al. 2007). Thus, an understanding of the ecology of the larvae of these salamanders will be important for understanding the conditions necessary for these threatened and endemic species to persist. Diets of larval Ambystoma can be affected by the quality of the habitat. For example, the diet of Ambystoma ordinarium in Mexico differed between disturbed and undisturbed reaches of a stream (Ruiz-Martínez et al. 2014), and wastewater contamination reduces prey consumption by $A$. mexicanum (Chaparro-Herrera et al. 2013). Thus, examining the diets of larval A. rivulare can provide insight into the suitability of the habitat to support the population of salamanders. We also were able to consider the presence and abundance of nematodes in the stomachs of these larvae.

\section{Materials and Methods}

\section{Study Site}

The population of Ambystoma rivulare that we studied inhabits a permanent stream that runs on the northwestern side of the Volcán Nevado de Toluca, state of México (Figure 1). The small stream receives water from Río La Fábrica and from two natural springs and runs through the middle of the town of Buenavista $\left(19^{\circ} 12^{\prime} 23.9^{\prime \prime} \mathrm{N}\right.$, 99'49'13.2" W; 3,148 m elevation). The terrain at this site has an average slope of $25^{\circ}$, resulting in a constant flow of water. There are several shallow swampy areas along flat sections of the stream that are 2-5 $\mathrm{m}$ wide depending on the season. Before reaching Buenavista, the stream divides into two small streams separated by about $70 \mathrm{~m}$ of human habitations. Downstream the stream divides into multiple small, narrow channels, approximately $25 \mathrm{~cm}$ wide and 20-30 $\mathrm{cm}$ deep.

The east side of the stream is bordered by a dense forest of Oyamel Fir (Abies religiosa) and by extensive grassland of Fescue (Festuca spp.) and Muhly Grass (Muhlenbergia spp.). This grassland is approximately $3 \mathrm{~km}$ long and $1 \mathrm{~km}$ wide. In and near the town of Buenavista secondary growth grasses and other plants grow along the stream. Most of the stream often contains refuse, such as car tires, tin cans, plastic bags, and metal pieces (Figure 2). In some parts the bottom of the stream substrate is extremely soft, consisting of a mud layer typically 15-25 $\mathrm{cm}$ deep but in some areas greater than $50 \mathrm{~cm}$ deep. The stream consistently has a salinity of $0.1 \mathrm{ppt}$, mean $( \pm 1 \mathrm{SE})$ water temperature of $16.12 \pm 0.13^{\circ} \mathrm{C}$, and mean dissolved oxygen content of $5.09 \pm 0.16 \mathrm{mg} \mathrm{L}^{-1}$. The average width of the stream was $1.93 \pm 0.08 \mathrm{~m}$, and the average depth was $71.6 \pm 1.85 \mathrm{~cm}$. Ambystoma rivulare 


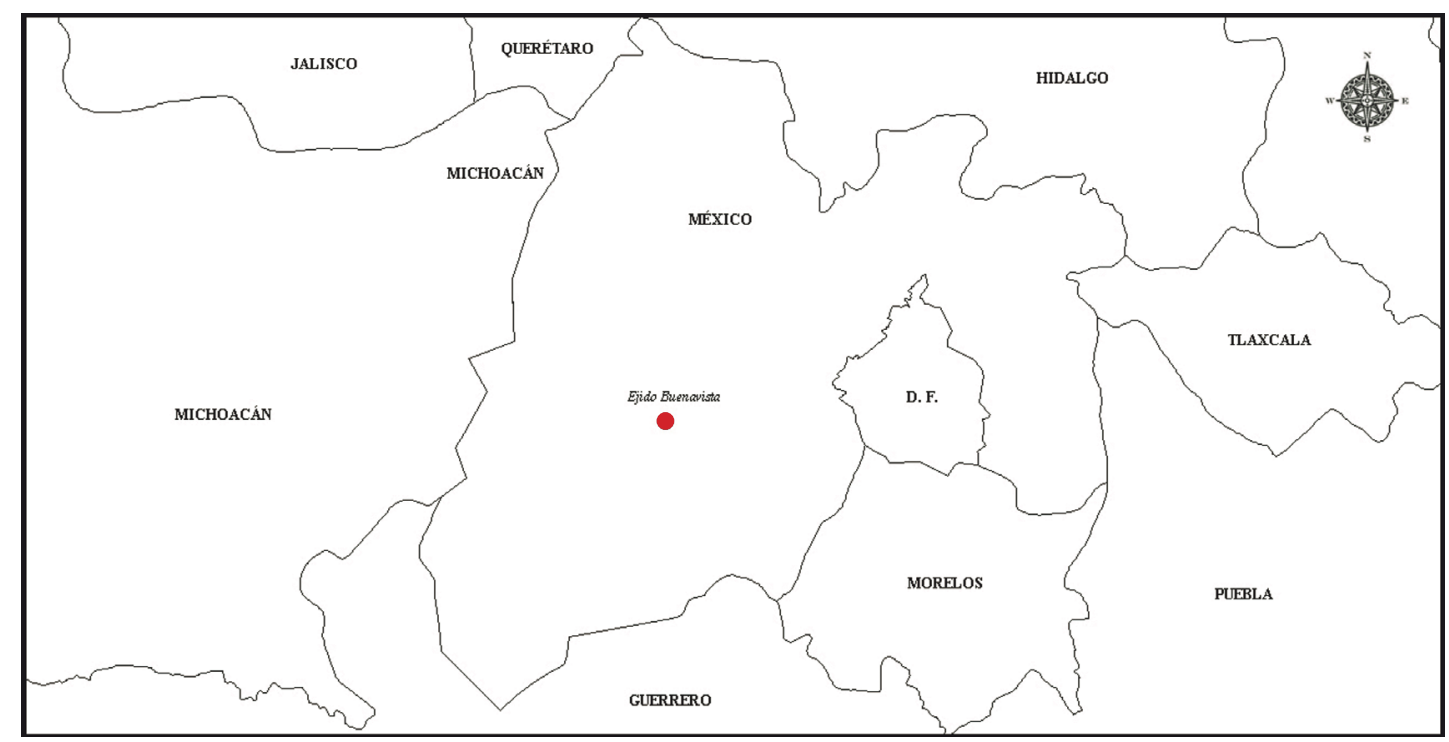

Figure 1. Map depicting the study locality in the state of México.

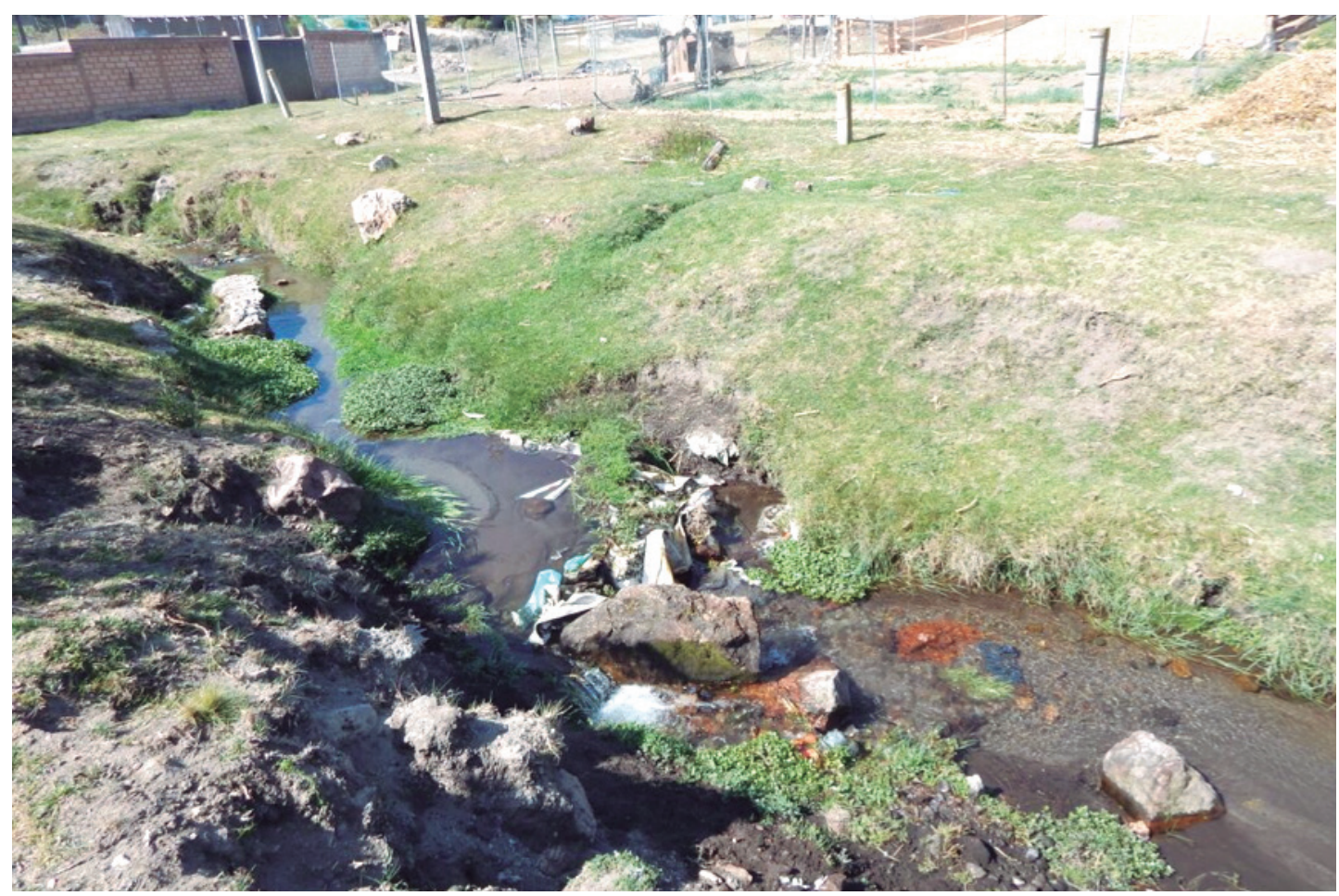

Figure 2. Photograph of example location along the studied stream. Note the presence of trash and refuse in the stream and the proximity to human dwellings. 
is common in the part of the stream that runs near and through the town, where they find refuge under refuse, in the dense mud of the bottom, and in the eroded sides of the stream.

\section{Methods}

We visited the study site monthly from October 2013 to September 2014. We observed individuals of larval Ambystoma rivulare in all months, except for December, January, and February, when the stream had dried up. Larval salamanders were captured by dip net and by hand. Using the stomach flushing technique (Legler and Sullivan 1979, Cecala et al. 2007), we obtained stomach contents for all captured individuals $\geq 35 \mathrm{~mm} \mathrm{SVL}$ and did not collect stomach contents from smaller individuals. Once we obtained the stomach contents, we released salamanders at the site of capture. Stomach contents were preserved in $95 \%$ ethanol and later counted and identified to the lowest taxonomic level possible using a stereoscopic microscope and the reference keys Borror et al. (1989), Borror and White (1998), Arnett (2000), and Eaton and Kaufman (2007).

Due to small sample sizes for each month (March, $N=4$; April, $N=7$; May, $N=6$; June, $N=7$; July, $N=10$; August, $N=9$; September, $N=9$; October, $N=4$; November, $N=4$ ), we pooled diet data for all months for our analyses. To examine if prey consumption was associated with larval body size, we tested for relationships between larval total length and number of ostracods, gastropods, and total prey items, as well as the proportion of ostracods and gastropods in the stomach using linear regressions.

\section{Results}

Mean SVL $( \pm 1$ SE) of the captured larval $A$. rivulare was $4.96 \pm 0.10 \mathrm{~cm}(N=60$, range $=$ $3.0-6.79 \mathrm{~cm})$. Mean tail length of the captured larvae was $4.31 \pm 0.10 \mathrm{~cm}(N=60$, range $=2.5$ $6.96 \mathrm{~cm})$. Mean total length was $9.17 \pm 0.19 \mathrm{~cm}$ $(N=60$, range $=5.5-13.75 \mathrm{~cm})$.
Of the larvae of A. rivulare examined, 55 contained prey items and five had no prey items (8.3\%). The diet of A. rivulare was overwhelmingly dominated by ostracods that accounted for approximately $90 \%$ of all prey items found in the stomachs (Table 1). Gastropods accounted for $9 \%$ of all prey items. Other prey taxa represented only about $1 \%$ of all identified prey. In terms of prey occurrence, nearly $71 \%$ contained ostracods, and approximately 50\% contained gastropods (Table 1). Coleoptera larvae were found in $14.5 \%$ of stomachs.

The total number of prey in individual stomachs increased with individual total length $\left(N=55, r^{2}=0.11 ; p=0.012\right.$; Total Prey Items $=$ $-127.0+19.8$ Total Length). The number of ostracods in the stomach contents increased with larval total length $\left(N=55, r^{2}=0.10, p=0.016\right.$; Ostracods $=-130.2+19.5$ Total Length). The proportion of prey items that were ostracods was not associated with larval body size $\left(N=55, r^{2}=\right.$ $0.004, p=0.64$; Proportion Ostracods $=0.42+$ 0.02 Total Length). The number of gastropods in the stomach contents was not associated with larval total length $\left(N=55, r^{2}=0.003, p=0.69\right)$. The proportion of prey items in a stomach that were gastropods was not associated with larval total length $\left(N=55, r^{2}=0.006, p=0.56\right)$.

We found a total of 310 nematodes in larval stomachs. Nematodes were found in 21 of the 60 stomachs that we examined $(35 \%)$. Mean $( \pm 1$ $\mathrm{SE})$ number of nematodes found in each occupied stomach was $14.8 \pm 4.8$.

\section{Discussion}

The larval Ambystoma rivulare we studied had a limited diversity of prey in their diets, potentially because of the relatively humanimpacted nature of the stream. Specifically, the diets of larval A. rivulare in our population were dominated by ostracods. Larval Ambystoma often consume ostracods, and they can be important prey items for some species (e.g., Tyler and Buscher 1990, Nyman 1991, Ghioca-Robrecht and Smith 2008, Regester et al. 2008). In streams 
Table 1. Stomach contents of Ambystoma rivulare $(N=55$ stomachs) from the Volcán Nevado de Toluca, state of México, Mexico. Percentages given in parentheses.

\begin{tabular}{|c|c|c|}
\hline Prey taxon & Prey Abundance & Prey Occurrence \\
\hline \multicolumn{3}{|l|}{ ANNELIDA } \\
\hline Hirudinea & $1(0.03)$ & $1(1.8)$ \\
\hline \multicolumn{3}{|l|}{ ARTHROPODA } \\
\hline Acari: Hydrophantidae & $9(0.30)$ & $4(7.3)$ \\
\hline Crustacea: Amphipoda & $3(0.1)$ & $1(1.8)$ \\
\hline Crustacea: Ostracoda & $2702(89.6)$ & 39 (70.9) \\
\hline Insecta: Coleoptera: Dytiscidae & $3(0.1)$ & $3(5.4)$ \\
\hline Insecta: Coleoptera - Larvae & $21(0.7)$ & $8(14.5)$ \\
\hline Insecta: Diptera - Larvae & $5(0.16)$ & $4(7.3)$ \\
\hline Insecta: Trichoptera - Larvae & $2(0.07)$ & $2(3.6)$ \\
\hline \multicolumn{3}{|l|}{ MOLLUSCA } \\
\hline Gastropoda & $271(9.0)$ & $29(52.7)$ \\
\hline Total & 3017 & 55 \\
\hline
\end{tabular}

of the Transvolcanic Belt, ostracods are more abundant in the stomachs of larval Michoacán Stream Salamander (Ambystoma ordinarium) in parts of the stream that are not disturbed by humans than in the stomachs of larvae from disturbed sites (Ruíz-Martínez et al. 2014). Our results do not appear to match this observation, since the section of stream that we sampled was highly disturbed by humans. We found that snails were consumed in this population of A. rivulare, but at a relatively low abundance compared to some other populations of larval Ambystoma in the streams near Mexico City (e.g., A. altamiranoi; Lemos-Espinal et al. 2015). Ruíz-Martínez et al. (2014) found that snail consumption by $A$. ordinarium was higher in areas with more human disturbance, and our observation of gastropods in the diet are higher than the $1-2 \%$ of physid snails found in the diet of A. ordinarium. These results suggest that any link between human disturbance, prey consumption, and prey availability in these streams needs to be more closely examined. In particular, studies that explore the effects of various human disturbances, such as pollution, refuse dumping, and water removal, on the abundance and distribution of specific potential prey taxa in the stream would help elucidate the possible underlying mechanisms of such a link. Such information could be critical to understanding how human alterations of stream environments impact the populations of these endemic and threatened salamanders. 
We found no evidence for a change in diet composition with the size of larval A. rivulare, although the number of prey consumed increased with larval body size. It should be noted our sample likely was biased towards larger larvae, since we were unable to obtain stomach contents from larvae $<3.5 \mathrm{~cm}$ in length (however, we were able to sample most of the captured larvae). A change in diet composition with body size is apparent in the larvae of other species of Ambystoma, including A. cingulatum (Whiles et al. 2004), A. jeffersonianum (Bardwell et al. 2007), A. talpoideum (Taylor et al. 1988), and A. tigrinum (Dodson and Dodson 1971, Brophy 1980, Holomuzki and Collins 1987, Zerba and Collins 1992). The absence of dietary shifts with larval size in $A$. rivulare may reflect the lack of availability of other, larger prey items in the stream studied. Indeed, diets of Ambystoma larvae are often variable among localities due to the availability of prey items in the environment (see Zerba and Collins 1982, Regester et al. 2008). Unfortunately, we did not quantitatively assess the environmental availability of prey items, however we observed abundant populations of ostracods in the stream where $A$. rivulare was collected, and that other prey items were not as abundant, at least in the shallow swampy areas where visibility allowed us to see potential prey more clearly.

We found no evidence for cannibalism in larval A. rivulare. Lemos-Espinal et al. (1999a) observed cannibalism in larval $A$. rivulare held in a small container. Lemos-Espinal et al. (1999a) further speculated that the spatial segregation of different sized larval A. rivulare into different parts of the stream that they observed (see also Bille 2009) was possibly a consequence of cannibalism. Our results suggest that this hypothesis may not be applicable in our system, and those other explanations, such as competition, may be driving any spatial size segregation among larvae. However, additional study will be necessary to fully explore these hypotheses, as well as the possibility that the relatively soft-bodies of larval salamanders might be digested more quickly than other prey items, and thus might be missed in a study examining stomach contents (although we do not believe this to be an issue in our study).

The proportion of empty stomachs in larval A. rivulare is somewhat higher than many other reports of 2 to $2.5 \%$ empty stomachs for larval Ambystoma (Flatwoods Salamander, Ambystoma cingulatum, Whiles et al. 2004; Mabee's Salamander, Ambystoma mabee, McCoy and Savitzky 2004; Eastern Tiger Salamander, Ambystoma tigrinum, Tyler and Buscher 1980). However, some species have similar or higher proportions of empty stomachs compared to A. rivulare. Bardwell et al. (2007) reported that $6 \%$ of larval Jefferson Salamander (Ambystoma jeffersonianum) stomachs were empty. For larval Mountain Stream Siredon (Ambystoma altamiranoi), another endangered Ambystoma from the environs of Mexico City, empty stomachs were found in $13.3 \%$ of the individuals examined (Lemos-Espinal et al. 2015). The relatively high proportion of empty stomachs suggests that the A. rivulare population we examined might be resource limited (see Huey et al. 2001). Given the fact that this stream is heavily impacted by humans, the empty stomachs may also reflect contamination of the water which has been shown to reduce foraging in larval $A$. mexicanum (Chapparro-Herrera et al. 2013). It may also be that the empty stomachs we observed were a result of other factors, such as timing of collection or body size of the larvae. However, these explanations seem unlikely since all larvae were caught at relatively similar times of day and the body sizes of those larvae with empty stomachs (SVL range: $3.39-6.79 \mathrm{~cm}$ ) encompassed nearly the entire range of body sizes we caught. Empty stomachs were also found in April $(N=2)$, June $(N=1)$, and July $(N=2)$, suggesting month is also unlikely to explain the pattern of empty stomachs.

Nematodes were observed in approximately one third of the stomachs of $A$. rivulare that we examined, with an average infection load of 15 nematodes per occupied stomach. We are assuming that these nematodes were parasitic in 
nature, and not prey items. This level of nematode infection is similar to the $34-45 \%$ of larval A. tigrinum with nematodes (Brophy 1980, Tyler and Buscher 1980). Nematodes were found in $94 \%$ of the stomachs of larval A. jeffersonianum (Bardwell et al. 2007). In contrast, nematode infection in $A$. rivulare is much lower than in larval A. jeffersonianum (94\%; Bardwell et al. 2007) and larval A. mabeei from Virginia (88.9\%; McCoy and Savitzky 2004), but substantially higher than larval A. mabeei in North Carolina (1.5\%; McCoy and Savitzky 2004). Broad variation in nematode infection loads suggests that examining abiotic and biotic factors that affect nematode infections among individuals, populations, and species of larval Ambystoma could inform our understanding of the potential for these nematodes to affect their hosts, especially if they could be related to environmental conditions or human disturbance.

In conclusion, the diversity of prey in the diet of $A$. rivulare in the stream we studied is limited and dominated by a single prey taxon, ostracods. The proportion of empty stomachs is relatively high. While our data come from a single population from a single stream, they do seem to indicate that the larvae of $A$. rivulare may be very dependent on a single prey item. Additional study of $A$. rivulare from other streams is necessary to determine how general our results are. Such information is critical to understanding how dependent these salamander larvae are on particular prey items and whether the importance of ostracods reflects environmental abundance or selection by the larvae. Therefore, continued investigation of the relationship between diet and environmental conditions for these larvae is needed to better understand the factors that will allow for the longterm persistence of this population of $A$. rivulare, and other endemic Ambystoma from Mexico.

\section{Acknowledgments}

All existing regulations regarding work with populations of Ambystoma altamiranoi were followed. Support for this study was provided by
Dirección General de Asuntos del Personal Académico - Programa de Apoyo a Proyectos de Investigación e Innovación Tecnológica (DGAPA-PAPIIT), through the project IN200114, and by Programa de Apoyo a los Profesores de Carrera (PAPCA) of FES-Iztacala UNAM through the project: 'Demografía e historia natural del Ajolote Arroyero de Toluca (Ambystoma rivulare), en la vertiente noroeste del Nevado de Toluca, Mexico.' We thank three anonymous reviewers for helpful comments on the manuscript.

\section{References}

Arnett, R. H. 2000. American Insects: A Handbook of the Insects of America North of Mexico. $2^{\text {nd }}$ Edition. Boca Raton. CRC Press. 1024 pp.

Bardwell, J. H., C. M. Ritzi, and J. A. Parkhurst. 2007. Dietary selection among different size classes of larval Ambystoma jeffersonianum (Jefferson Salamanders). Northeastern Naturalist 14: 293-299.

Bille, T. 2009. Field observations on the salamanders (Caudata: Ambystomatidae, Plethodontidae) of Nevado de Toluca, Mexico. Salamandra 45: 155-164.

Borror, D. J. and R. E. White. 1998. A Field Guide to Insects: America North of Mexico. $2^{\text {nd }}$ Edition. New York. Houghton Mifflin Company. 416 pp.

Borror, D. J., C. A. Triplehorn, and N. F. Johnson. 1989. An Introduction to the Study of Insects. New York. Harcourt Brace College Publishers. 875 pp.

Brandon, R. A. and R. G. Altig. 1973. Eggs and small larvae of two species of Rhyacosiredon. Herpetologica 29: 349351 .

Bride, I. G., R. A. Griffiths, A. Meléndez-Herrada, and J. E. McKay. 2008. Flying an amphibian flagship: conservation of the axolotl Ambystoma mexicanum through nature tourism at Lake Xochimilco, Mexico. International Zoological Yearbook 42: 116-124.

Brophy, T. E. 1980. Food habits of sympatric larval Ambystoma tigrinum and Notophthalmus viridescens. Journal of Herpetology 14: 1-6.

Cecala, K. K., S. J. Price, and M. E. Dorcas. 2007. Diet of larval red salamanders (Pseudotriton ruber) examined using a nonlethal technique. Journal of Herpetology 41: 741-745.

Chaparro-Herrera, D. de J., S. Nandini, and S. S. S. Sarma. 2013. Effect of water quality on the feeding ecology of axolotl Ambystoma mexicanum. Journal of Limnology 72: 555-563. 
Contreras, V., E. Martínez-Meyer, E. Valiente, and L. Zambrano. 2009. Recent decline and potential distribution in the last remnant area of the microendemic Mexican axolotl (Ambystoma mexicanum). Biological Conservation 142: 2881-2885.

Dodson, S. I. and V. E. Dodson. 1971. The diet of Ambystoma tigrinum larvae from western Colorado. Copeia 1971: $614-624$

Eaton, E. R. and K. Kaufman. 2007. Kaufman Field Guide to Insects of North America. New York. Houghton Mifflin Company. $392 \mathrm{pp}$.

Flores-Villela, O. A. 1993. Herpetofauana of Mexico: distribution and endemism. Pp. 253-280 in T. P. Ramamoorthy, R. Bye, A. Lot, and J. Fa (eds.), Biological Diversity of Mexico: Origins and Distribution. New York. Oxford University Press.

Frías-Alvarez, P., V. T. Vredenburg, M. Familiar-López, J. E. Longcore, E. González-Bernal, G. Santos-Barrera, L. Zambrano, and G. Parra-Olea. 2008. Chytridiomycosis survey in wild and captive Mexican amphibians. EcoHealth 5: $18-26$.

Frías-Alvarez, P., J. J. Zúñiga-Vega, and O. Flores-Villela. 2010. A general assessment of the conservation status and decline trends of Mexican amphibians. Biodiversity and Conservation 19: 3699-3742.

Ghioca-Robrecht, D. M. and L. M. Smith. 2008. Feeding ecology of polymorphic larval barred tiger salamanders in playas of the Southern Great Plains. Canadian Journal of Zoology 86: 554-563.

Griffiths, R. A., V. Graue, I. G. Bride, and J. E. McKay. 2004. Conservation of the axolotl (Ambystoma mexicanum) at Lake Xochimilco, Mexico. Herpetological Bulletin 89: 4-11.

Holomuzki, J. R. and J. P. Collins. 1987. Trophic dynamics of a top predator, Ambystoma tigrinum nebulosum (Caudata: Ambystomatidae), in a lentic community. Copeia 1987: 949-957.

Huacuz Elias, D. del C. 2003. Estado de conservación de Ambystoma rivulare Taylor (1940) en El Santuario Sierra Chincua de la Reserva de la Biosfera "Maripoda Monarca." Biológicas 5: 51-63.

Huey, R. B., E. R. Pianka, and L. J. Vitt. 2001. How often do lizards "run on empty"? Ecology 82: 1-7.

Legler, J. M. and L. J. Sullivan. 1979. The application of stomach-flushing to lizards and anurans. Herpetologica 35: $107-110$.

Legorreta-Balbuena, G., G. Gutiérrez-Ospina, I. Villalpando Fierro, and G. Parra-Olea. 2014. Ambystoma rivulare (Toluca siredon) reproduction. Herpetological Review 45: 107-108.

Lemos-Espinal, J. A., R. E. Ballinger, and G. R. Smith. 1999a. Ambystoma rivulare. (Michoacan stream siredon). Cannibalism. Herpetological Review 30: 159.
Lemos-Espinal, J. A., G. R. Smith, R. E. Ballinger, and A. Ramírez-Bautista. 1999b. Status of protected endemic salamanders (Ambystoma: Ambystomatidae: Caudata) in the Transvolcanic Belt of Mexico. British Herpetological Society Bulletin 68: 1-4.

Lemos-Espinal, J. A., G. R. Smith, and G. A. Woolrich-Piña. 2015. Diet of larval Ambystoma altamiranoi from Llano de los Axolotes, Mexico. Current Herpetology 34: 75-79.

McCoy, M. W. and A. H. Savitzky. 2004. Feeding ecology of larval Ambystoma mabeei (Urodela: Ambystomatidae). Southeastern Naturalist 3: 409-416.

Nyman, S. 1991. Ecological aspects of syntopic larvae of Ambystoma maculatum and the A. laterale-jeffersonianum complex in two New Jersey ponds. Journal of Herpetology 25: 505-509.

Regester, K. J., M. R. Whiles, and K. R. Lips. 2008. Variation in the trophic basis of production and energy flow associated with emergence of larval salamander assemblages from forest ponds. Freshwater Biology 53: $1754-1767$.

Robles-Mendoza, C., C. García-Basilio, S. Cram-Heydrich, M. Hernández-Quiroz, and C. Vanegas-Pérez. 2009. Organophosphorus pesticides effect on early stages of the axolotl Ambystoma mexicanum (Amphibia: Caudata). Chemosphere 74: 703-710.

Ruiz-Martínez, L., J. Alvarado-Díaz, I. Suazo-Ortuño, and R. Pérez-Munguía. 2014. Diet of Ambystoma ordinarium (Caudata: Ambystomatidae) in undisturbed and disturbed segments of a montane stream in the trans-Mexican Volcanic Belt. Salamandra 50: 63-70.

Taylor, B. E., R. A. Estes, J. H. K. Pechmann, and R. D. Semlitsch. 1988. Trophic relations in a temporary pond: larval salamanders and their microinvertebrate prey. Canadian Journal of Zoology 66: 2191-2198.

Tyler, J. D. and H. N. Buscher. 1980. Notes on a population of larval Ambystoma tigrinum (Ambystomatidae) from Cimarron County, Oklahoma. Southwestern Naturalist 25: 391-395.

Whiles, M. R., J. B. Jensen, J. G. Palis, and W. G. Dyer. 2004. Diets of larval flatwoods salamanders, Ambystoma cingulatum, from Florida and South Carolina. Journal of Herpetology 38: 208-214.

Zambrano, L., E. Vega, M. L. G. Herrera M., E. Prado, and V. H. Reynoso. 2007. A population matrix model and population viability analysis to predict the fate of endangered species in highly managed water systems. Animal Conservation 10: 297-303.

Zerba, K. E. and J. P. Collins. 1992. Spatial heterogeneity and individual variation in diet of an aquatic top predator. Ecology 73: 268-279. 